\title{
MSH6 Loss of Nuclear Expression
}

National Cancer Institute

\section{Source}

National Cancer Institute. MSH6 Loss of Nuclear Expression. NCI Thesaurus. Code C160418.

An indication that expression of MSH6 was not detected in the nuclei of cells in a sample. 